Original Article

Integrated Environmental Assessment and Management

DOI 10.1002/ieam.1706

\title{
Integrated assessment of climate change impact on surface runoff contamination by pesticides**
}

Running head: Climate change impact on pesticides in surface runoff

\author{
Patrick GAGNON ${ }^{\dagger *}$, Claudia SHEEDY ${ }^{*}$, Alain N. ROUSSEAU ${ }^{\S}$, Gaétan BOURGEOIS ${ }^{\|}$, Gérald \\ CHOUINARD ${ }^{\#}$
}

\footnotetext{
${ }^{\dagger}$ Agriculture and Agri-Food Canada, 2560, boulevard Hochelaga, Québec city, QC, Canada, G1V $2 J 3$. (patrick.gagnon@agr.gc.ca; Phone: 1-418-657-7980; Fax: 1-418-648-2402)

*Agriculture and Agri-Food Canada, 5403 1st Ave South, Lethbridge, AB, Canada, T1J 4B1. (claudia.sheedy@agr.gc.ca)

${ }^{\S}$ Institut National de la Recherche Scientifique, Centre Eau Terre Environnement, 490 de la Couronne, Québec city, QC, Canada, G1K 9A9. (alain.rousseau@ete.inrs.ca)

Agriculture and Agri-Food Canada, 430 boulevard Gouin, St-Jean-sur-Richelieu, QC, Canada, J3B

7B5. (gaetan.bourgeois@agr.gc.ca)

"Institut de Recherche et de Développement en Agroenvironnement, 335 chemin des Vingt-Cinq Est, Saint-Bruno-de-Montarville, QC, Canada, J3V 0G7. (gerald.chouinard@irda.qc.ca)

* To whom correspondence may be addressed.
}

${ }^{* *}$ This article has been accepted for publication and undergone full peer review but has not been through the copyediting, typesetting, pagination and proofreading process, which may lead to differences between this version and the Version of Record. Please cite this article as doi: [10.1002/ieam.1706]

All Supplemental Data may be found in the online version of this article at the publisher's website.

This article is protected by copyright. All rights reserved Submitted 29 December 2014; Returned for Revision 24 August 2015; Accepted 24 August 2015 


\section{ABSTRACT}

Pesticide transport by surface runoff depends on climate, agricultural practices, topography, soil characteristics, crop type, and pest phenology. To accurately assess the impact of climate change, these factors must be accounted for in a single framework by integrating their interaction and uncertainty. This paper presents the development and application of a framework to assess the impact of climate change on pesticide transport by surface runoff in southern Québec (Canada) for the 1981-2040 period. The crop enemies investigated were: weeds for corn (Zea mays); and for apple orchard (Malus pumila), three insect pests (codling moth (Cydia pomonella), plum curculio (Conotrachelus nenuphar) and apple maggot (Rhagoletis pomonella)) and two diseases (apple scab (Venturia inaequalis) and fire blight (Erwinia amylovora)). A total of 23 climate simulations, 19 sites, and 11 active ingredients were considered. The relationship between climate and phenology was accounted for by bioclimatic models of the Computer Centre for Agricultural Pest Forecasting (CIPRA) software. Exported loads of pesticides were evaluated at the edge-of-field scale using the Pesticide Root Zone Model (PRZM), simulating both hydrology and chemical transport. A stochastic model was developed to account for PRZM parameter uncertainty. Results of this study indicate that for the 2011-2040 period, application dates would be advanced from 3 to 7 days on average with respect to the 1981-2010 period. However, the impact of climate change on maximum daily rainfall during the application window is not statistically significant, mainly due to the high variability of extreme rainfall events. Hence for the studied sites and crop enemies considered, climate change impact on pesticide transported in surface runoff is not statistically significant throughout the 2011-2040 period. This article is protected by copyright. All rights reserved

Key words: integrated assessment modelling, pesticide, runoff, CIPRA, PRZM. 


\section{INTRODUCTION}

Cultivar selection, seeding dates, pesticide selection and timing of applications, as well as crop infestations are strongly related to climate. Under changing climate conditions (Intergovernmental Panel on Climate Change; IPCC 2013), new agricultural market opportunities may arise, but unforeseen threats may appear as well. Among the possible threats, climate change could induce an increase in pesticide applications, leading to an increase in pesticide loads transported in the environment by surface runoff, groundwater contamination or atmospheric deposition.

Since pre-industrial times, anthropogenic activities have induced a $40 \%$ increase in $\mathrm{CO}_{2}$ atmospheric concentration (IPCC 2013). This $\mathrm{CO}_{2}$ concentration is expected to rise during the next decades, even under optimistic scenarios (IPCC 2013). From 1986-2005 to 2046-2065, the increase in mean global temperature is expected to be between 0.4 and $2.6^{\circ} \mathrm{C}$ (IPCC 2013). Warmer temperatures may induce migration of crop enemies toward the poles (Wolfe et al. 2008), increase the abundance of enemies (Hakala et al. 2011), and increase the number of generations of pests during the growing season (Luedeling et al. 2011; Hirschi et al. 2012; Juszczak et al. 2013), leading to a subsequent increase in pesticide use. Warmer temperatures may also advance the growth period, along with application dates (Hirschi et al. 2012), and accelerate biodegradation of pesticides (Bloomfield et al. 2006; Shymko et al. 2011; Balbus et al. 2013; Steffens et al. 2013), possibly reducing exported loads per application, but also possibly leading to more applications (Bloomfield et al. 2006). Increase in $\mathrm{CO}_{2}$ may particularly benefit $\mathrm{C}_{3}$ plants, either crops or weeds (Stratonovitch et al. 2012). The competitiveness of corn (Zea mays), a $\mathrm{C}_{4}$ plant, could then be reduced compared to $\mathrm{C}_{3}$ weeds (Wolfe et al. 2008).

Climate change impact on precipitation is more uncertain. Some studies show that rainfall events should become more frequent and more intense (e.g., Dayyani et al. 2012; Mailhot et al. 2012), but it might not be the case for all regions and all temporal horizons (e.g., Sunyer et al. 2012; Centre 
d'expertise hydrique du Québec, CEHQ 2013). Higher intensity rainfall events soon after pesticide application would potentially increase the amount of pesticides transported in surface runoff. For regions such as southern Québec, where longer and more intense summer droughts are expected (CEHQ, 2013), in-stream pesticide concentrations might increase (Bloomfield et al. 2006).

Very few studies include impacts of climate change on both pesticide applications and loads transported by surface runoff (e.g., Koleva and Schneider 2010; Kattwinkel et al. 2011). The objective of this study was to develop a framework to assess the impact of climate change on the pesticide amount transported in surface runoff. Overall, climate change impacts on pesticide applications and risk of water contamination depend on crops, enemies, regions and temporal horizon. The developed framework was applied to corn (Zea mays) for weed treatments and to apple (Malus pumila) for treatments against three insect pests (codling moth (Cydia pomonella), plum curculio (Conotrachelus nenuphar) and apple maggot (Rhagoletis pomonella)) and two diseases (apple scab (Venturia inaequalis) and fire blight (Erwinia amylovora)). This study focused on southern Québec (Canada) over the 1981-2040 period.

The choice of crop enemies was motivated by their relative importance in the study area and worldwide. Herbicides are the most applied pesticides for corn in Québec. Numerous herbicides were found in river samplings of some Québec watersheds with a high intensity of corn production (Giroux and Pelletier, 2012). In some cases, concentrations exceeded water quality criteria for the protection of aquatic life. In recent years, with new glyphosate-tolerant cultivars available for corn and soybeans, glyphosate became the most applied active ingredient (AI) in Québec (Giroux and Pelletier, 2012).

Codling moth is an important pome fruit pest insect around the world and its presence in Québec is continuously increasing, being now considered the number one insect pest in apple orchards (Chouinard 2014a). Currently in Québec, there are up to two generations of codling moth per year. Some studies have suggested that the number of generations of codling moth per year could further 
increase in the future (e.g., Luedeling et al. 2011; Hirschi et al. 2012; Juszczak et al. 2013). Plum curculio is one of the most important pests for pome and stone fruits in eastern North America (Chouinard 2014b; Hock et al. 2014). In Québec, apple maggot started to cause serious damages to apples at the beginning of the $20^{\text {th }}$ century and is present in Mexico, United States and throughout eastern Canada, except Newfoundland (Canadian Food Inspection Agency, CFIA 2012).

Apple scab treatment is responsible for most fungicide applications for apple in most non-arid areas (Carisse et al. 2008). It is the most important apple disease in eastern Canada. Using five climate model simulations for a single Québec site, Bourgeois et al. (2004) indicated that in the future, the beginning of the first infection period would be earlier, while the beginning of the last infection period would remain stable, resulting in an increase in the number of infection periods. Fire blight is present throughout the world and is an important apple disease in the three most important Canadian provinces where apples are produced, namely Ontario, Québec and British Columbia (Svircev 2012). Giayetto and Rossini (2011) observed an increase in the risk of fire blight infection on pear in Argentina during the 1970-2009 period. Hirschi et al. (2012) used climate model data to evaluate the evolution of the risk of infection in Switzerland. They concluded that the infection period would start earlier in the future (2045-2074), but the risk of infection would remain stable.

Five components were integrated in our study: climate model data, bioclimatic model data, agricultural management scenarios, pesticide transport model, and a stochastic model. For each site, climate simulation and AI, one hundred (100) 60-year runs were performed using a Monte Carlo approach. Climate change impact was assessed in terms of exported loads of pesticides at the edge-offield scale. As agricultural practices (e.g., cultivars used, products applied, and application methods) continuously evolve, thanks to new technologies and market demand, an evaluation beyond 2040 was not considered. 


\section{METHODS}

2.1 Case Study

This study focused on corn (for grain or for silage) and apple productions in Québec, Canada.

Ten sites (fields) for corn and nine sites (orchards) for apple were identified (Figure 1). The sites were selected using a database of the Financière Agricole du Québec for the year 2012. They are representative of areas where both crops are cultivated. Agricultural activities in Québec are concentrated in the south, facilitated by a continental wet climate, especially in the St. Lawrence Lowlands, having arable soils and a flat topography (Gouvernement du Québec 2014).

The soil type for each site was identified using maps provided by the Institut de Recherche et de Développement en Agroenvironnement (IRDA 2013). For each soil type, soil properties were retrieved from the national soil database of Agriculture and Agri-Food Canada (AAFC 2010). Digital elevation model data came from GeoGratis, a portal of Natural Resources Canada (NRC 2014). All datasets are available online.

As each crop-enemy combination has its own relationship with climate, only some specific enemies were studied. For corn, only herbicide applications were considered. For apple, insecticide applications against codling moth, plum curculio and apple maggot, fungicide applications against apple scab, and bactericide applications against fire blight were considered. The application scenarios were related to climate and are detailed later on.

\subsection{Integrated modelling}

This section details the five components integrated in the modelling framework, illustrated in Figure 2.

\subsubsection{Climate Models}

Daily precipitation and temperature data were obtained from 23 climate model simulations generated by four different global models using three different greenhouse gas (GHG) emission scenarios (Table S1 in supplemental data). These scenarios were based on economic and technological 
evolution scenarios from the year 2000 (Nakicenovic and Swart 2000). Prior to 2000, GHG emissions were based on global observations for all climate simulations. The simulations cover the 1961-2100 period, but only the 1981-2040 period was used in the present study.

Dynamical downscaling was applied on four global model simulations with the Canadian Regional Climate Model (CRCM) version 4.2 (Caya and Laprise 1999; Paquin 2010). Dynamical downscaling refines the spatial resolution of the simulated values, from hundreds to less than fifty kilometers. However, spatial resolution of climate model remains too low, even after dynamical downscaling, to accurately reproduce meteorological data at the field scale. To circumvent this issue, a statistical downscaling technique called daily translation (Mpelasoka and Chiew 2009) was applied to all climate model simulations. The technique proceeds as follows. Let $X$ be a raw simulated daily value (temperature or precipitation directly from a climate model, before statistical downscaling) and $p$ the proportion of all simulated daily values during a reference period for that time of the year $( \pm 15$ calendar days) that are smaller than $X$. In other words, $p$ is the empirical cumulative distribution function for the simulated past for that time of the year evaluated at $X$. The corrected daily value is the $p$-fractile of the distribution of the observed values during a reference period for that time of the year. In this study, the observed data came from a $0.1^{\circ}$-resolution meteorological grid (approximately $10 \mathrm{~km}$ ) used by NRC (Hutchinson et al. 2009; Hopkinson et al. 2011) and the reference period was 1961-2000. For a given site, the downscaled data of the NRC grid point closest to the field centroid were retained. Daily potential evapotranspiration was estimated from the modified Penman-Monteith equation (Allen et al. 1998).

\subsubsection{Bioclimatic Models}

Bioclimatic models link weather to phenology of species (crops or enemies). Table S2 (supplemental data) presents how the relevant phenological stages were defined in this work. These stages were used to determine pesticide application windows (more details in the next subsection). 
Emergence and maturation were also used to define parameter values of the transport model related to land cover.

Almost all values of growing degree days (GDD) were set based on the models available in the Computer Centre for Agricultural Pest Forecasting (CIPRA) software (Plouffe et al. 2014). The models for crops and insects were calibrated and validated with data from southern Québec. These GDD values were assumed to remain valid as climate change occurs.

\subsubsection{Agricultural Management Scenarios}

This subsection describes the seeding, harvest and pesticide application scenarios defined for each year for each crop. They are based on expert judgements and on decision-making tools for producers, when available.

The growing season for corn was assumed to start after the last spring ground frost as soon as the mean temperature over the previous five days reached $12.8^{\circ} \mathrm{C}$ (AgWeather Québec 2012). The seeding occurred within the week following the start of the growing season, assuming producers would like to maximize crop production.

Two herbicide application scenarios were considered: pre-emergence and post-emergence treatments. For each scenario, the application date was randomly selected among the days within the GDD interval (Table S2) and receiving less than $1 \mathrm{~mm}$ of rain, to minimise runoff losses. For both scenarios, one treatment per year was performed. The AIs considered (atrazine, mesotrione, glyphosate) and corresponding application rate intervals and chemical properties are shown in Table S3 (supplemental data). For the post-emergence scenario, it was assumed that glyphosate-tolerant corn would be seeded.

Harvest occurred during the two weeks preceding the end of the growing season. The end of the growing season was estimated from AgWeather Québec (2012). Fall conventional tillage, which 
modifies some land cover parameters of the transport model, was simulated the following day. Note that the exact dates of harvest and fall tillage are not important with regards to the modelling exercise, as they occur long after the herbicide application.

To control the three insect pests considered for apple, three applications per year were simulated. The first treatment was against plum curculio and the second and third treatments focused on the first and second generations of the codling moth, respectively (Table S2). The third treatment was also used against the apple maggot. As the period considered is relatively short from a climatic point of view, it was assumed that the warming would not be sufficient to allow a third generation of codling moth in Québec by 2040. Four insecticides (acetamiprid, phosmet, spinetoram, thiacloprid) were considered (Table S3) and it was assumed that the same insecticide could be used for the three applications. As for herbicides, the application date was randomly selected among the days within the GDD interval (Table S2) receiving less than $1 \mathrm{~mm}$ of rain. If all days within the interval received more than $1 \mathrm{~mm}$ of rain, additional days were included, namely one day before the first day and one day after the last day of the interval. Apple harvest was assumed to occur in the last two weeks of September.

Fungicide application scenarios are more complicated as they depend on humidity, in addition to temperature and phenological stages of apple trees. For apple scab, it was assumed that producers would apply a fungicide if the three following conditions were met: (i) the target day is within the ascospore ejection period (Table S2), (ii) the last treatment is no longer efficient, and (iii) the leaf wetness duration threshold is reached. The last treatment was considered no longer efficient if it occurred more than two days before and if at least one of the three following statements was true: (i) at least five leaves (cluster + terminal shoots) appeared since the last treatment, (ii) $25 \mathrm{~mm}$ of rain had fallen from two days after the last treatment and the day following the target day, or (iii) the last treatment occurred more than 10 days before. The relationship between number of leaves and GDD is provided by Carisse and Jobin (2006), as well as the relationship between leaf wetness duration 
threshold and temperature. This scenario does not necessarily represent the decision process used by all apple producers, but it is a realistic scenario against primary infections in Québec (Roland Joannin, Agropomme, personal communication). It was assumed that no additional applications were needed against secondary infections. Three AIs were considered (captan, mancozeb, metiram; Table S3).

The fire blight infection period was assumed to occur between full pink and petal fall (Table S2). The application scenario was based on the decision support model CougarBlight 2010 (Smith 2010). An application occurred if the cumulative risk value over the last four days exceeded 100, which is the lower threshold for the "CAUTION" risk level for the default scenario for eastern USA ("blight history scenario 2") in Smith (2010). Daily risk value depends on temperature and the calculation method is provided in Smith (2010). Another condition for treatment would be that flowers were wet by light rain or dew for more than two hours (Smith 2010), but this criterion was not considered in this study. No more than one application per four-day period and three applications per year were possible. Only one bactericide, streptomycin sulfate, was considered (Table S3).

Note that contrary to herbicides and insecticides, fungicide and bactericide treatments may occur on rainy days. Also note that all pesticides were assumed to be sprayed, with foliage interception proportional to crop development stage. Spray drift was not considered.

\subsubsection{Pesticide Transport Model}

Pesticide Root Zone Model (PRZM) version 3.12.3 (Suarez 2005) was selected as the pesticide transport model. Developed by the US Environmental Protection Agency (USEPA), and freely available at http://www2.epa.gov/exposure-assessment-models/przm-version-index, PRZM is a onedimensional model that simulates pesticide transport in the vertical soil column of the crop root zone. It simulates concentrations and loads at the edge-of-field scale. It does not simulate the transport of pesticide through the broader environment (e.g., streams, basin outlets). PRZM has been used extensively and several studies have shown that the model produces reasonable estimates (e.g., 
Carbone et al. 2002; Singh and Jones 2002; Warren-Hicks et al. 2002; Farenhorst et al. 2009) while requiring relatively low computational time (McQueen et al. 2007).

Input data include daily weather (precipitation, temperature, potential evapotranspiration), soil properties of each layer, crop characteristics, pesticide application information (e.g., dates, rate, method used) and soil cover properties, amongst others. The model has two basic components: hydrology and chemical transport. For the purpose of the present study, the most important hydrological process is surface runoff and is mainly driven by the runoff curve number, a well-defined empirical parameter that depends on soil properties and land cover (United-States Department of Agriculture, USDA 2004). Pesticide may be transported in surface runoff by soil erosion, which is simulated using three empirical equations, all based on the Universal Soil Loss Equation (USLE) developed by the USDA (Wischmeier and Smith 1978). For chemical properties, past studies (e.g., Dubus and Janssen 2003; Dann et al. 2006; Farenhorst et al. 2009; Luo et al. 2011; Rousseau et al. 2012) suggest that the most important variables for chemical transport in surface runoff are adsorption coefficient, which is the product of $K_{\mathrm{oc}}$ (Table S3) and soil organic carbon content, and the half-life (Table S3), defining the decay rates. The most important PRZM parameters are identified in Table S5 (supplemental data). For a complete description of the model, the reader is referred to Suarez (2005).

\subsubsection{Stochastic Model}

For a given site and AI, uncertainty about climate change was accounted for by the use of 23 climate model simulations. A stochastic model, modified from Gagnon et al. (2014), was developed to also account for uncertainty related to agricultural management practices, soil properties and processes simulated by PRZM. Each of these components is represented by a group of PRZM parameters. For each relevant PRZM parameter, a probability distribution was defined (Table S5). For some PRZM parameter distributions, the mean and the standard deviation were assumed to be site-specific, but the distribution and its higher order moments are identical for all sites. The mean of the distributions was 
estimated from the AAFC (2010) dataset for soil property parameters and from PRZM guidelines (Suarez, 2005) for the other parameters. As no calibration data were available, the standard distribution of the distributions was relatively large to cover the "true" value of each parameter. Correlations between soil parameters were also accounted for (Table S5). Note that seeding, harvest and application dates were also included in the stochastic model (Figure 2); the selected date followed a discrete uniform distribution over the set of eligible dates determined in the subsection "Agricultural management scenarios". A probability distribution was defined for a total of 22 parameters.

Prior to PRZM simulations, a matrix of $100 \times 22$ pseudo-random values from the uniform- $(0,1)$ distribution were generated. For each combination site-AI-climate-simulation, 100 different 60-year PRZM simulations, referred to as realizations, were performed using a Monte-Carlo approach. The parameter values for the $i^{\text {th }}$ PRZM simulation $(i=\{1, \ldots, 100\})$ were generated from their probability distribution (Table S5) by inverse transform sampling of the $i^{\text {th }}$ line of the matrix of pseudo-random values. A total of 14,076,000 years were simulated in this work.

\subsection{Statistical Analyses}

Climate change may impact pesticide loads transported in surface runoff by changing the application period (timing and number of treatments) and precipitation regime. The retained variables related to application period are herbicide (corn) and insecticide (apple) application dates, as well as the start of the infection period, the duration of the infection period and the number of applications against both diseases considered (apple scab and fire blight). For these variables, thirty-year averages (19812010 vs 2011-2040) were calculated for each combination site-climate-simulation.

Preliminary analyses showed that over the 60-year period (1981-2040), about 85\% of the total simulated pesticide load transported comes from the 60 maximum annual daily loads, on average. It highlights the fact that these maximum annual daily loads mainly occur during the first intense precipitation event following an application. Thus, the variable retained for precipitation is the 
maximum annual daily rainfall occurring within or close to the application period. For a given combination site-climate-simulation-year, two types of intervals were considered: one centered at the median application date among the candidate days for the given year, referred to as moving interval, and another centered at the median application date calculated using all years (i.e., same dates for all years), referred to as fixed interval. Fixed intervals allow evaluating the climate change impact on a specific time of the year, as it is commonly performed in impact assessment studies, while moving intervals account for inter-annual climate variability affecting decisions made by producers (e.g., a warmer spring induces sooner herbicide applications). These intervals were calculated separately for pre-emergence and post-emergence herbicide applications (corn) and for the three insecticide applications (apple). Interval duration was set to 31 days (median +/- 15 days) for herbicide and to 11 days (median +/- 5 days) for insecticide applications, corresponding approximately to the respective length of the application periods. Maximum annual daily rainfall, during fixed or moving intervals, varies highly from year to year. Thus, thirty-year averages are not informative. Instead, the nonparametric Mann-Kendall test (Mann 1945; Kendall 1970) was applied to evaluate whether there is an increasing or a decreasing trend in the median for the 60-year maximum daily rainfall series. The nonparametric Mood test (Conover, 1971) was also performed to evaluate the statistical significance of the 30-year differences between past and future variances. These tests are accurate even when the normality assumption is violated.

The fact that a large proportion of the annual load comes from the maximum annual daily load also implies that the daily maximum and the total annual loads have a similar behavior. While, for some applications, both daily maximum and total annual load values need to be analyzed (e.g., evaluation of acute and chronic exposures), the relative impact of climate change may be analyzed on one of the two only. In the present work, total annual loads were analyzed. Thirty-year mean pesticide loads (1981-2010 and 2011-2040) were calculated for each combination site-climate-simulation-AI- 
realization. In order to evaluate the relative impact of the 30-year mean changes, the standard deviation of each source of uncertainty was calculated. Also, for each of the 102 site-AI combinations considered, empirical 90\% inter-realization (with climate simulation results averaged together) and inter-climate-simulation (with the 100 PRZM realization results averaged together) confidence intervals were calculated.

A sensitivity analysis, based on the approach used in Dubus and Janssen (2003), was performed separately on each AI in order to identify the relative influence of each parameter on 60-year mean annual pesticide loads and on 30-year mean annual changes (1981-2010 vs 2011-2040). A multiple linear regression was performed with the dependent variable vector being the inter-site and interclimate-simulation mean of the response variable (60-year mean annual pesticide loads or 30-year mean annual changes) for each realization (100 values) and the independent variables being the pseudo-random values from the uniform- $(0,1)$ distribution for each parameter and each realization $(100$ x 22 values). For a given parameter, a regression coefficient far from 0 indicates that the response variable is sensitive to variation of the parameter value.

\section{RESULTS}

First, the impact of climate change is assessed with respect to the application period (timing and number of treatments) and to precipitation. Then, the impact is evaluated in terms of the variable of interest, the exported loads of pesticides in surface runoff (sum of dissolved and adsorbed pesticides).

\subsection{Climate Change Impact on Application Period}

All climate simulations agree that pesticide application dates will be earlier in the future for the weeds and insects considered (Figure 3). The mean advancement from past (1981-2010) to future (2011-2040) goes from 3.5 days earlier in the season (pre-emergence herbicide and first insecticide applications) to 7 days at the end of the season (third insecticide application). From all 1081 siteclimate-simulation-application combinations, the mean application date is earlier for the past compared 
to the future in only 39 cases $(3.6 \%)$ and it never happens for the third insecticide application. Note that for some rare cases, a third insecticide application was not simulated (GDD requirement not reached). Herbicide and insecticide application dates are only driven by spring and summer temperatures. As inferred by the results displayed on Figure 3, these temperatures are expected to increase for southern Québec over the next three decades.

For both diseases considered, infection periods would also be earlier by 2 or 3 days on average (Figure 4a). For the sites considered, total duration of infection periods for apple scab and fire blight would last between 35 and 45 days, and between 10 and 15 days, respectively. Because of warmer temperatures in the future, the duration of infection periods for apple scab and fire blight would, on average, slightly decrease, by 1.2 days, and 0.4 day, respectively (Figure 4b). These small changes would not result in any significant changes in the number of annual applications (Figure 4c).

\subsection{Climate Change Impact on Precipitation}

Evolution in time of the median of the maximum daily rainfall during the moving interval is analyzed through the Mann-Kendall test for the period 1981-2040 for each site-climate-simulation combination (Table 1). For the pre-emergence herbicide treatment, results indicate a possible increase in maximum annual precipitation, with $6.1 \%$ of significant positive trends at $5 \%$ level and $63.5 \%$ for positive trends overall. There is a possible decrease for the second insecticide treatment, with $7.2 \%$ of significant negative trends at $5 \%$ level and $62.3 \%$ for negative trends overall. Otherwise, maximum daily rainfall during the application period remains stable during the 1981-2040 period.

Table 2 presents the results of the Mann-Kendall test, but for the fixed interval, centered at the interannual median application day. For the post-emergence herbicide and second insecticide applications, the number of total positive trends is substantially larger using the fixed interval (Table 2) compared to moving interval (Table 1). However, the proportion of positive trends remains stable for the other cases. Figure 5 shows the impact of the difference between moving and fixed intervals on the 
maximum daily rainfall for post-emergence herbicide application. In this case, it illustrates that when the application period is early in the season, the maximum daily precipitation tends to be lower.

Evolution in time of the variance of the maximum daily rainfall during the moving interval (Table 3) and the fixed interval (Table 4) is analyzed through the Mood test for the period 1981-2040 for each site-climate-simulation combination. There are two main findings. First, the variance is generally more likely to increase when considering fixed intervals (Table 4) compared to moving intervals (Table 3). Second, the variance is increasing for a significant number of simulations for the second insecticide application. This application occurs in summer, when intense and highly, spatially variable, convective events are frequent.

\subsection{Climate Change Impact on Transported Pesticide Loads in Surface Runoff}

Table 5 shows the mean transported pesticide loads in surface runoff (1981-2040) and the mean change between past (1981-2010) and future (2011-2040) for each AI, along with the standard deviation of each source of uncertainty. The loads are the sum of dissolved and adsorbed pesticides. In most cases, dissolved pesticide loads are larger than adsorbed pesticide loads.

Overall, mean annual pesticide loads transported correspond to less than $1 \%$ of the total mass of AI applied, which is comparable to other surface runoff loads reported in the literature (Wauchope 1978; Bloomfield et al. 2006; Rousseau et al. 2012). The loads transported in proportion of mass applied per treatment can be larger when considering shorter timeframes (e.g., daily).

Estimated mean loads (1981-2040) vary significantly between sites, AIs and realizations. The inter-site and inter-realization standard deviations are often larger than the mean load values. Sites with high runoff curve number and slope values are more likely to produce large loads. Percent of soil organic carbon may also have an impact, but it does not vary much between sites, which does not allow for a clear evaluation of the impact of this variable. AIs with larger half-life and/or lower $K_{\mathrm{oc}}$ values 
(Table S3) will produce larger loads. With respect to the stochastic model, the large differences between realizations are mainly due to the runoff curve number parameter (CN, Table S5, Figure 6a), positively correlated with the mean load. The maximum infiltration depth of pesticides, the DEPI parameter (Table S5, Figure 6a), is another important variable explaining differences between realizations. Its value is negatively correlated with the mean load. For the AIs with a high $K_{o c}$ value (Table S3), the organic carbon content (OC parameter) is also important (Table S5, Figure 6a). The inter-climate-simulation standard deviation is small, between 5 to 10 times smaller than the mean load. It means that the choice of the climate simulation has only a small effect on the mean load over the period 1981-2040.

Mean pesticide load changes between 1981-2010 and 2011-2040 are generally low (Table 5). The largest mean increase is for fungicide applications to control apple scab (between +8.2 and $+11.5 \%)$, but the increase is smaller than the inter-site and inter-climate-simulation standard deviations and approximately equal to inter-realization standard deviation. Contrary to the mean loads, the largest standard deviation is associated with the inter-climate-simulation variability (represented by the 23 simulations). For a given treatment type, some climate simulations produce systematically larger loads for the future while other climate simulations produce systematically larger loads for the past on all sites. Overall, these systematic increases or decreases are caused by only one extreme event that occurred just after the pesticide application period (for simulations producing a decrease, during the 1981-2010 period; and for simulations producing an increase, during the 2011-2040 period). These increases or decreases cannot be associated to GHG scenarios, as some climate simulations with the same GHG scenario return contradictory outcomes. Besides, mean load change (1981-2010 vs 20112040) is weakly sensitive to variations of the PRZM parameter values (Figure 6b); thus any changes are primarily driven by climate projections. 
For each of the 102 site-AI combinations, mean loads for the past (1981-2010) and mean load changes (1981-2010 vs 2011-2040) were calculated and accompanied with two 90\% confidence intervals, accounting for inter-realization and inter-climate-simulation variability. The $90 \%$ interclimate-simulation interval includes the value of 0 for the mean load change for all the 102 combinations. Thus, none of the considered cases studied show a significant increase for the future because of the high inter-climate-simulation variability. When averaging climate simulation results together and considering the inter-realization variability only, the 30-year pesticide load (dissolved phase only) significantly increases (90\% level) in the future for 28 combinations and significantly

decreases for 9 combinations out of 102 . However, the inter-realization confidence interval does not consider future climate uncertainty.

\section{DISCUSSION}

In order to assess the impact of climate change on exported pesticide loads in surface runoff, the proposed framework accounts for climate impact on the phenology of crop and enemy using bioclimatic models within CIPRA (Plouffe et al. 2014), along with pesticide transport model parameter and climate uncertainty. As each interaction crop-enemy-climate is unique, the assessment was made on some specific crops and crop enemies in Québec: weeds in corn, three insects (codling moth, plum curculio and apple maggot) and two diseases (apple scab and fire blight) in apple trees.

For each enemy, AIs among the most used in Québec were considered. In order to isolate the impact of climate, the pesticide loads were simulated at the field/orchard scale (10 sites for corn, 9 for apple) using the one-dimensional model PRZM version 3.12.3 (Suarez 2005) assuming that agricultural practices not linked to climate were time invariant. As agricultural practices (e.g., cultivars selected, AIs used) are continuously evolving, the study was limited to the period 1981-2040. While studies focusing on further temporal horizons (e.g., 2041-2070, 2071-2100) fully exploit the climate change signal simulated by climate models, studies focusing on nearer horizons are more suited to evaluate the 
need for adaptation by the agricultural sector, considering currently available management practices and technology. A total of 23 climate simulations, coming from three GHG emission scenarios, different models and different members of the same model were used (Table S1). This methodology provided a means of accounting for the uncertainty associated with the evolution of the GHG emissions, the climate model physical representation and the "natural" variability of the climate.

According to the climate simulations used, it can be mentioned with high confidence that applications would occur sooner in the future due to the increase in temperature. The mean changes between 1981-2010 and 2011-2040 would be about 3 days for early spring applications against fire blight to 7 days for the third insecticide application occurring in the second half of the summer (Figures 3 and 4). The increase in temperature does not significantly affect the number of applications against both diseases considered (Figure 4). These findings corroborate those reported by Hirschi et al. (2012) for fire blight.

Simulated maximum daily precipitation during the application period does not significantly increase nor decrease for the sites studied. This can be explained as follows. First, the temporal series are relatively short. From a climatic perspective, longer series would have allowed to capture a stronger climate change signal. From a statistical point of view, longer time series would have permitted to strengthen the power of the statistical test (e.g., increase the probability to detect a trend, given that there is a trend). Second, higher temperatures could lead to stronger precipitation events, but this effect could be hidden by the large variability of extreme events. It is probably the case in southern Québec. Indeed, CEHQ (2013) used 89 climate simulations to compare summer and autumn peak flows and found no significant change between the periods 1971-2000 and 2041-2070 due to the high dispersion of the climate model results. The results of the present study show that the simulated variability of maximum rainfall is likely to increase for the near future, especially for the second insecticide application in the summer (Tables 3 and 4). It is possibly due to an increase of convective rainfall 
events (Gagnon and Rousseau, 2014). Third, in some cases such as post-emergence herbicide applications in corn (Tables 1 and 2, Figure 5), bringing earlier in the future the application temporal window reduces the probability to "hit" a high precipitation event. It also attenuates the increase of the variability of the maximum daily rainfall (Tables 3 and 4). The fact that agricultural producers already modulate their activities according to the weather may represent an intrinsic form of adaptation to climate change.

It results that the mean climate change impact on pesticide loads in surface runoff is not significant in most cases studied (Table 5). Analyses on the three GHG scenarios did not permit to detect any systematic effect of the GHG scenario (not shown). The GHG scenario effect could be stronger for a longer study period. While the site, the AI and the PRZM parameter set used have a significant effect on the absolute value of the exported loads, the effect of these three sources of uncertainty is relatively small on the absolute value of load change between 1981-2010 and 2011-2040 (Table 5). This fact provides confidence in the results presented herein; even though only one pesticide transport model was used and no in-situ calibration data per se were available for the estimation of PRZM parameter values and AI chemical properties.

The runoff curve number (CN, Table S5, Figure 6a), the depth of pesticide infiltration (DEPI, Table S5, Figure 6a), half-life and $K_{\mathrm{oc}}$ of the AI (Table S3) are the most important PRZM parameters. While the inter-climate-simulation mean change in pesticide load is small, the high inter-climatesimulation variability indicates that pesticide load is very sensitive to climate and that the spectrum of possible change for the near future is large. As producers already manage pesticide applications according to the weather, the uncertain climate evolution needs to be accounted for. When applicable, avoiding pesticide applications just before intense rainfall events, implementing soil conservation practices reducing runoff, and use of less persistent and less mobile AIs would help to reduce pesticide loads transported, climate change or not. Simulations performed with soil incorporated atrazine 
produced a load reduction of about $75 \%$ in surface runoff compared to sprayed pesticides (not shown). However, soil incorporation is only possible for some herbicides.

Other factors not considered here could affect the exported pesticide loads under future climate conditions. Among those related to the climate, migration to the north of some crop enemies could increase pesticide use (Wolfe et al. 2008). Also, the dependence of AI properties to climate, as for example the acceleration of biodegradation when temperature increases (Bloomfield et al. 2006; Steffens et al. 2013), was not considered. Resistance of crop enemies to pesticides could also increase under warmer conditions (Bloomfield et al. 2006). Warmer conditions could also lead to more convective rainfall events (Gagnon and Rousseau, 2014), which are more intense and shorter than frontal precipitations. In this study, only daily precipitation depth was considered and the statistical method used to downscale climate model data (Mpelasoka and Chiew 2009) does not account for potential change in the proportion of convective and frontal precipitations. Integrating this change could increase the impact of climate change on pesticide loads in surface runoff since more intense precipitations generate more pesticide removal for a given precipitation depth (Hunsche et al., 2007).

There are several factors not considered which are not directly linked to climate but could also modify pesticide use in the future. For example, new technologies, such as the development of pestresistant cultivars and the use of less persistent, less mobile or less toxic AIs, could reduce the risk of water contamination by pesticides. On the other hand, new cultivars tolerant to a persistent and/or mobile and/or toxic AI could increase application and consequently the risk of water contamination. For river contamination, land cover evolution in the watershed (e.g., increase of urban and/or agricultural areas, deforestation) might have an important impact on water quality, even more important than climate change (Quilbé et al. 2008; Savary et al. 2009; Poelmans et al. 2011). 


\section{CONCLUSION}

The objective of the study was to assess the impact of climate change on the pesticide transport load for some crop enemies typically found in Québec during the 1981-2040 period. Weeds in corn, three insect pests and two diseases affecting apple trees were considered. The developed framework integrates the various sources of uncertainty in order to accurately isolate the impact of the factor of interest (climate change in the present study).

Assuming that the 23 climate simulations used cover adequately the spectrum of possible projections, our results suggest that the variability is too high to affirm that climate change would have an impact on mean pesticide loads in surface runoff at the field scale for the 1981-2040 period for the sites with the crop enemies considered. Due to this high variability, periodic evaluations of the evolution of the climate are recommended. The impact of climate change was clearly detected on application dates, which would be advanced in the future due to the temperature increase, but the number of applications against both diseases considered would remain stable during the next 30 years. Maximum daily precipitation during the application period would not significantly increase in the near future, but its variability is likely to increase, especially during summer applications. It did not result in a significant increase of the exported pesticide loads in the present study, but might represent a management issue for the producers and increase the vulnerability of the environment.

Exported pesticide loads are very dependent on the timing between pesticide applications and the intensity of the following precipitation event. In this context, accurate local-scale weather forecasting tools would help producers to avoid applying just before a rainfall event. Also, agricultural management practices reducing runoff, soil incorporation of herbicides, and the use of less persistent, less mobile and less toxic AIs represent different measures that could be considered to reduce pesticide loads transported, when applicable. 
The findings of this study are specific to the crop enemies, region (southern Québec) and period (1981-2040) considered at the field/orchard scale and the evolution in time of the pesticide exported loads only accounted for the direct climate change impact. Pesticide exported loads in surface runoff could actually change in the future due to other external factors.

\section{ACKNOWLEDGEMENTS}

This project was funded by Agriculture and Agri-Food Canada (AAFC). Climate model data were downscaled and supplied by Ouranos, consortium on regional climatology and adaptation to climate change. The authors would like to thank Jean-François Martineau for providing the data from the Financière Agricole du Québec as well as Anne Blondlot and Blaise Gauvin St-Denis (Ouranos), René Audet (AAFC), Pierre Lafrance (Institut National de la Recherche Scientifique, INRS), Isabelle Beaudin and Vincent Philion (Institut de Recherche et de Développement en Agroenvironnement, IRDA), Roland Joannin (Agropomme), Isabelle Giroux and Jean-Thomas Denault (Ministère du Développement durable, de l'Environnement et de la Lutte contre les changements climatiques, MDDELCC), Danielle Bernier and Pierre-Antoine Thériault (Ministère de l'Agriculture, des Pêcheries et de l'Alimentation du Québec MAPAQ), and the anonymous reviewers for their valuable comments and suggestions.

\section{SUPPLEMENTAL DATA}

"gagnon_et_al_2015_suppData.doc" containing:

Table S1: Climate model simulations used.

Table S2: Phenological parameters retained for agricultural management scenarios.

Table S3: Active ingredients used for each application scenario.

Table S4: IUPAC name of each active ingredient.

Table S5: Most important PRZM parameters with their probability distribution. 


\section{REFERENCES}

AAFC, Soil Landscapes of Canada Working Group. 2010. Soil Landscapes of Canada version 3.2 (digital map and database at 1:1 million scale) [Internet]. [Cited 2014 June 6]. Available at: http://sis.agr.gc.ca/cansis/nsdb/slc/v3.2/index.html

AgWeather Québec. 2012. Formulation des indices agroclimatiques [Internet]. [Cited 2014 June 12]. Available at: http://www.agrometeo.org/atlas/display_guide/Formules_atlas_agroclim_2012_v8.pdf [In French]

Allen RG, Pereira LS, Raes D, Smith M. 1998. Crop evapotranspiration - Guidelines for computing crop water requirements - FAO Irrigation and drainage paper 56. FAO - Food and Agriculture Organization of the United Nations, Rome. ISBN 92-5-104219-5.

Balbus JM, Boxall ABA, Fenske RA, McKone TE, Zeise, L. 2013. Implications of global climate change for the assessment and management of human health risks of chemicals in the natural environment. Environ Toxicol Chem 32(1): 62-78.

Bloomfield JP, Williams RJ, Gooddy DC, Cape JN, Guha P. 2006. Impacts of climate change on the fate and behaviour of pesticides in surface and groundwater - a UK perspective. Sci Tot Environ 369: 163-177.

Bourgeois G, Bourque A, Deaudelin G. 2004. Modelling the impact of climate change on disease incidence: a bioclimatic challenge. Can J Plant Pathol 26: 284-290.

Carbone JP, Havens PL, Warren-Hicks W. 2002. Validation of pesticide root zone model 3.12: Employing uncertainty analysis. Environ Toxicol Chem 21(8): 1578-1590.

Carisse O, Jobin T. 2006. Apple scab: Improving understanding for better management - Agriculture and Agri-Food Canada [Internet]. [Cited 2014 June 12] Available at: http://www.agr.gc.ca/eng/science- 
and-innovation/science-publications-and-resources/technical-factsheets/apple-scab-improvingunderstanding-for-better-management/?id=1234199585484

Carisse O, Jobin T, Bourgeois G. 2008. Predicting apple leaf emergence from degree-day accumulation during the primary scab period. Can J Plant Sci 88: 229-238.

Caya D, Laprise R. 1999. A semi-implicit semi-lagrangian Regional Climate Model: The Canadian RCM. Mon Weather Rev 127: 341-362.

CEHQ. 2013. Atlas hydroclimatique du Québec méridional - Impact des changements climatiques sur les régimes de crue, d'étiage et d'hydraulicité à l'horizon 2050. Québec, 2013, 51 pp. [In French]

CFIA. 2012. Rhagoletis pomonella (Apple Maggot) - Fact Sheet [Internet]. [Cited 2014 June 6] Available at: http://www.inspection.gc.ca/plants/plant-protection/insects/apple-maggot/factsheet/eng/1330366145611/1330366375524

Chouinard G. 2014a. Guide de référence en production fruitière intégrée à l'intention des producteurs de pommes du Québec. Institut de recherche et de développement en agroenvironnement, Québec, QC. p. 76-1. [In French]

Chouinard G. 2014b. Guide de référence en production fruitière intégrée à l'intention des producteurs de pommes du Québec. Institut de recherche et de développement en agroenvironnement, Québec, QC. p. 72-1. [In French]

Conover WJ. 1971, Practical nonparametric statistics. John Wiley \& Sons, New York, USA, 462 pages.

Dann RL, Close ME, Lee R, Pang L. 2006. Impact of data quality and model complexity on prediction of pesticide leaching. J Environ Qual 35: 628-640. 
Dayyani S, Prasher SO, Madani A, Madramootoo CA. 2012. Impact of climate change on the hydrology and nitrogen pollution in a tile-drained agricultural watershed in eastern Canada. Trans ASABE 55(2): 389-401.

Dubus IG, Janssen PHM. 2003. Issue of replicability in Monte Carlo modeling: A case study with a pesticide leaching model. Environ Toxicol Chem 22(12): 3081-3087.

Farenhorst A, McQueen DAR, Saiyed I, Hilderbrand C, Li S, Lobb DA, Messing P, Schumacher TE, Papiernik SK, Lindstrom MJ. 2009. Variations in soil properties and herbicide sorption coefficients with depth in relation to PRZM (pesticide root zone model) calculations. Geoderma 150: 267-277.

Gagnon P, Rousseau AN. 2014. Stochastic spatial disaggregation of extreme precipitation to validate a Regional Climate Model and to evaluate climate change impacts over a small watershed. Hydrology and Earth System Sciences 18: 1-10.

Gagnon P, Sheedy C, Farenhorst A, McQueen DAR, Cessna AJ, Newlands, N. 2014. A coupled stochastic/deterministic model to estimate the evolution of the risk of water contamination by pesticides across Canada. Integrated Environmental Assessment and Management 10(3): 429-436.

Giayetto A, Rossini M. 2011. Prediction of Symptoms Occurrence of Fire Blight (Erwinia amylovora) by the MARYBLYT ${ }^{\mathrm{TM}}$ Program in Río Negro, Argentina. Acta Hort 909: 517-520.

Giroux I, Pelletier L. 2012. Présence de pesticides dans l'eau au Québec : bilan dans quatre cours d'eau de zones en culture de maïs et de soya en 2008, 2009 et 2010, Québec, ministère du Développement durable, de l'Environnement et des Parcs, Direction du suivi de l'état de l'environnement, ISBN 978-2550-64159-9 (PDF), 46 pp. and 3 annexes. [in French]

Gouvernement du Québec. 2014. Geology : Québec Portal [Internet]. [Cited 2014 June 6]. Available at: http://www.gouv.qc.ca/portail/quebec/pgs/commun/portrait/geographie/geologie/?lang=en 
Hakala K, Hannukkala AO, Huusela-Veistola E, Jalli M, Peltonen-Sainio P. 2011. Pests and diseases in a changing climate: a major challenge for Finnish crop production. Agric Food Sci 20: 3-14.

Hirschi M, Stoeckli S, Dubrovsky M, Spirig C, Calanca P, Rotach MW, Fischer AM, Duffy B, Samietz J. 2012. Downscaling climate change scenarios for apple pest and disease modeling in Switzerland. Earth Sys Dynam 3: 33-47.

Hock V, Chouinard G, Lucas É, Cormier D, Leskey T, Wright S, Zhang A, Pichette A. 2014. Establishing abiotic and biotic factors necessary for reliable male pheromone production and attraction to pheromones by female plum curculios Conotrachelus nenuphar (Coleoptera: Curculionidae). Can Entomol 146(5): 528-547.

Hopkinson RF, McKenney DW, Milewska EJ, Hutchinson MF, Papadopol P, Vincent LA. 2011. Impact of aligning climatological day on gridding daily maximum-minimum temperature and precipitation over Canada. J Appl Meteor and Climatol 50: 1654-1665.

Hunsche M, Damerow L, Schmitz-Eiberger M, Noga G. 2007. Mancozeb wash-off from apple seedlings by simulated rainfall as affected by drying time of fungicide deposit and rain characteristics. Crop protection 26: 768-774.

Hutchinson MF, McKenney DW, Lawrence K, Pedlar JH, Hopkinson RF, Milewska EJ, Papadopol P. 2009. Development and testing of Canada-wide interpolated spatial models of daily minimummaximum temperature and precipitation for 1961-2003. J Appl Meteor and Climatol 48: 725-741.

IPCC. 2013. Summary for policymakers. In Stocker, T.F., D. Qin, G.-K. Plattner, M. Tignor, S.K. Allen, J. Boschung, A. Nauels, Y. Xia, V. Bex, and P.M. Midgley (eds). Climate Change 2013: The physical science basis. Contribution of Working Group I to the fifth assessment report of the IPCC. Cambridge University Press, Cambridge, United Kingdom and New York, NY, USA, 27 pp. 
IRDA. 2013. Feuillets cartographiques [Internet]. [Cited 2014 June 6]. Available at: http://www.irda.qc.ca/fr/outils-et-services/informations-sur-les-sols/etudes-pedologiques/feuilletscartographiques/ [In French]

Juszczak R, Kuchar L, Leśny J, Olejnik J. 2013. Climate change impact on development rates of the codling moth (Cydia pomonella L.) in the Wielkopolska region, Poland. Int J Biometeorol 57: 31-44.

Kattwinkel M, Kühne JV, Foit K, Liess M. 2011. Climate change, agricultural insecticide exposure, and risk for freshwater communities. Ecol Appl 21(6): 2068-2081.

Kendall MG. 1970. Rank Correlation Methods, $4^{\text {th }}$ ed., Griffin, Londres.

Koleva NG, Schneider UA. 2010. The impact of climate change on aquatic risk from agricultural pesticides in the US. Int J Environ Stud 67(5): 677-704.

Luedeling E, Steinmann KP, Zhang M, Brown PH, Grant J, Girevetz EH. 2011. Climate change effects on walnut pests in California. Glob Change Biol 17: 228-238.

Luo Y, Spurlock F, Deng X, Gill S, Goh K. 2011. Use-exposure relationships of pesticides for aquatic risk assessment. PLoS ONE 6(4): art. no. e18234.

Mailhot A, Beauregard I, Talbot G, Caya D, Biner S. 2012. Future changes in intense precipitation over Canada assessed from multi-model NARCCAP ensemble simulations. Int J Climatol, 32(8): 11511163.

Mann HB. 1945. Nonparametric tests against trend, Econometrica 13: 245-259.

McQueen DAR, Farenhorst A, Allaire S, Cessna AJ. 2007. Automation and evaluation of three pesticide fate models for a national analysis of leaching risk in Canada. Can J Soil Sci 87(2): 203-212. 
Mpelasoka FS, Chiew FHS. 2009. Influence of rainfall scenario construction methods on runoff projections, J Hydromet 10: 1168-1183.

Nakicenovic N, Swart R (eds.). 2000. IPCC special report on emissions scenarios: a special report of Working Group III of the IPCC. Cambridge, UK, 599 p.

NRC. 2014. Geospatial Data Extraction [Internet]. [Cited 2014 June 6] Available at: http://geogratis.gc.ca/site/eng/extraction/

Paquin D, 2010. Évaluation du MRCC4 en passé récent (1961-1999). Rapport interne No 15: Ouranos, Équipe Simulations climatiques. [In French]

Plouffe D, Bourgeois G, Beaudry N, Chouinard G, Choquette D. 2014. CIPRA - Centre Informatique de Prévision des Ravageurs en Agriculture. Agriculture and Agri-Food Canada, Publication No. 12147F. 138 p. [Internet] [Cited 2014 December 8] Available at: http://www.agrireseau.qc.ca/documents/Document_88744.PDF [In French]

Poelmans L, Rompaey AV, Ntegeka V, Willems P. 2011. The relative impact of climate change and urban expansion on peak flows: a case study in central Belgium. Hydrol Process 25: 2846-2858.

Quilbé R, Rousseau AN, Moquet JS, Savary S, Ricard S, Garbouj MS. 2008. Hydrological responses of a watershed to historical land use evolution and future land use scenarios under climate change conditions. HESS 12: 101-110.

Rousseau AN, Lafrance P, Lavigne MP, Savary S, Konan B, Quilbé R, Amrani M, Jiapizan P. 2012. A hydrological modelling framework for defining watershed-scale achievable performance standards of pesticides beneficial management practices. J Environ Qual 41(1): 52-63.

Savary S, Rousseau AN, Quilbé R. 2009. Assessing the effects of historical land cover changes on runoff and low flows using remote sensing and hydrological modeling. J Hydrol Eng 14(6): 575-587 
Shymko JL, Farenhorst A, Zvomuya F. 2011. Polynomial response of 2,4-D mineralization to temperature in soils at varying soil moisture contents, slope positions and depths. J Environ Sci Heal B 46: $301-312$.

Singh P, Jones RL. 2002. Comparison of pesticide root zone model 3.12: runoff predictions with field data. Environ Toxicol Chem 21(8): 1545-1551.

Smith TJ. 2010. CougarBlight 2010. Washington State University Extension [Internet]. [Cited 2014 June 12] Available at: http://county.wsu.edu/chelandouglas/agriculture/treefruit/Pages/Cougar_Blight_2010.aspx

Steffens K, Larsbo M, Moeys J, Jarvis N, Lewan E. 2013. Predicting pesticide leaching under climate change: Importance of model structure and parameter uncertainty. Agric Ecosyst Environ 172: 24-34.

Stratonovitch P, Storkey J, Semenov MA. 2012. A process-based approach to modelling impacts of climate change on the damage niche of an agricultural weed. Glob Change Biol 18: 2071-2080.

Suarez LA. 2005. PRZM-3, A model for predicting pesticide and nitrogen fate in the crop root and unsaturated soil zones: User's manual for release 3.12.2. EPA/600/R-05/111. Athens (GA), USA: U.S. Environmental Protection Agency, National Exposure Research Laboratory, Ecosystems Research Division [Internet]. [Cited 2014 June 13] Available at: http://www.epa.gov/athens/publications/reports/Suarez600R05111PRZM3.pdf

Sunyer MA, Madsen H, Ang PH. 2012. A comparison of different regional climate models and statistical downscaling methods for extreme rainfall estimation under climate change, Atmos Res 103: 119-128. 
Svircev, A. 2012. Screening of novel materials for the control of fire blight in Canadian orchards. In Agriculture and Agri-Food Canada [Internet]. [Cited 2014 June 6]. Available at: http://www.agr.gc.ca/eng/?id=1299093979054

USDA, Natural Resources Conservation Service. 2004. Chapter 9 - Hydrologic soil-cover complexes. In National engineering handbook - Part 630, Hydrology. USDA NRCS. Washington (DC), USA [Internet]. $\quad$ [Cited June 2014 Available http://directives.sc.egov.usda.gov/OpenNonWebContent.aspx?content=17758.wba

Warren-Hicks W, Carbone JP, Havens PL. 2002. Using Monte Carlo techniques to judge model prediction accuracy: Validation of the Pesticide Root Zoot Model 3.12. Environ Toxicol Chem 21(8): $1570-1577$.

Wauchope, RD. 1978. The pesticide content of surface water draining from agricultural fields - A review. J Environ Qual 7(4): 459-472.

Wischmeier WH, Smith DD. 1978. Predicting rainfall erosion losses: A guide to conservation planning. USDA, Agriculture Handbook 537. U.S. Government Printing Office, Washington, DC.

Wolfe DW, Ziska L, Petzoldt C, Seaman A, Chase L, Hayhoe K. 2008. Projected change in climate thresholds in the Northeastern U.S.: implications for crops, pests, livestock, and farmers. Mitig Adapt Strategies Glob Change 13: 555-575. 


\section{LIST OF FIGURES}

Figure 1. Corn (green circles) and apple (red circles) sites retained for this study.

Figure 2. Conceptual model of the integrated components for a given site and a given active ingredient (AI). Each box illustrates a component (boldface) with its outcomes. Inputs for each component are illustrated by incoming arrows.

Figure 3. Mean application dates in the past (1981-2010) and in the future (2011-2040) against (a) weeds (corn; circles for pre-emergence, squares for post-emergence) and (b) insects (apple; circles for $1^{\text {st }}$, squares for $2^{\text {nd }}$ and triangles for $3^{\text {rd }}$ application) considered for each site-climate-simulation combination. The continuous line is the 1:1 relationship. The dashed lines are the mean changes.

Figure 4. (a) Mean start date of infection periods, (b) mean duration of infection periods and (c) mean number of applications against apple scab (circles) and fire blight (squares) in the past (1981-2010) and in the future (2011-2040) for each of the 207 site-climate-simulation combinations.

Figure 5. Proportion of the maximum daily rainfalls occurring during the moving interval that are at least $10 \mathrm{~mm}$ larger (blue bars) or at least $10 \mathrm{~mm}$ smaller (red bars) than those occurring during the fixed interval for the 13,800 site-climate-simulation-year combinations of post-emergence herbicide applications.

Figure 6. Sensitivity of (a) the 60-year mean annual pesticide load (1981-2040) and (b) the 30-year mean annual pesticide load change (1981-2010 vs 2011-2040) to parameter values. The relative sensitivity is the ratio of the regression coefficient on the interannual mean load for each AI. Parameter names (more details in Table S5): $\mathrm{CN}=$ runoff curve number, DEPI $=$ infiltration depth, $\mathrm{OC}=$ organic carbon content, SLP = slope, TAPP $=$ application rate, THEFC and THEWP $=$ field capacity and wilting point. 
Table 1. Mann-Kendall test results for the maximum daily rainfall (1981-2040) during the moving interval of 31-day (herbicide) or 11-day (insecticide) centered on the median application day at each year for each site-climate-simulation combination.

\begin{tabular}{|c|c|c|c|c|c|}
\hline \multirow{2}{*}{$\begin{array}{l}\text { Treatment } \\
\text { (crop) }\end{array}$} & \multirow{2}{*}{$\begin{array}{l}\text { Number } \\
\text { of tests }\end{array}$} & \multicolumn{2}{|c|}{ Number of positive trends } & \multicolumn{2}{|c|}{ Number of negative trends } \\
\hline & & $p$-value $<5 \%$ & Total & $p$-value $<5 \%$ & Total \\
\hline $\begin{array}{l}\text { Pre-emergence } \\
\text { herbicide (corn) }\end{array}$ & 230 & $\begin{array}{c}14 \\
(6.1 \%)\end{array}$ & $\begin{array}{c}146 \\
(63.5 \%)\end{array}$ & $\begin{array}{c}2 \\
(0.9 \%)\end{array}$ & $\begin{array}{c}84 \\
(36.5 \%)\end{array}$ \\
\hline $\begin{array}{l}\text { Post-emergence } \\
\text { herbicide (corn) }\end{array}$ & 230 & $\begin{array}{c}6 \\
(2.6 \%)\end{array}$ & $\begin{array}{c}111 \\
(48.3 \%)\end{array}$ & $\begin{array}{c}1 \\
(0.4 \%)\end{array}$ & $\begin{array}{c}118 \\
(51.3 \%)\end{array}$ \\
\hline $\begin{array}{c}1^{\text {st }} \text { insecticide } \\
\text { treatment (apple) }\end{array}$ & 207 & $\begin{array}{c}4 \\
(1.9 \%)\end{array}$ & $\begin{array}{c}112 \\
(54.1 \%)\end{array}$ & $\begin{array}{c}4 \\
(1.9 \%)\end{array}$ & $\begin{array}{c}94 \\
(45.4 \%)\end{array}$ \\
\hline $\begin{array}{l}2^{\text {nd }} \text { insecticide } \\
\text { treatment (apple) }\end{array}$ & 207 & $\begin{array}{c}6 \\
(2.9 \%)\end{array}$ & $\begin{array}{c}77 \\
(37.2 \%)\end{array}$ & $\begin{array}{c}15 \\
(7.2 \%)\end{array}$ & $\begin{array}{c}129 \\
(62.3 \%)\end{array}$ \\
\hline $\begin{array}{l}3^{\text {rd }} \text { insecticide } \\
\text { treatment (apple) }\end{array}$ & 207 & $\begin{array}{c}6 \\
(2.9 \%)\end{array}$ & $\begin{array}{c}107 \\
(51.7 \%)\end{array}$ & $\begin{array}{c}12 \\
(5.8 \%)\end{array}$ & $\begin{array}{c}100 \\
(48.3 \%)\end{array}$ \\
\hline
\end{tabular}


Table 2. Mann-Kendall test results for the maximum daily rainfall (1981-2040) during the fixed interval of 31-day (herbicide) or 11-day (insecticide) centered on the interannual median application day for each site-climate-simulation combination.

\begin{tabular}{|c|c|c|c|c|c|}
\hline \multirow{2}{*}{$\begin{array}{l}\text { Treatment } \\
\text { (crop) }\end{array}$} & \multirow{2}{*}{$\begin{array}{l}\text { Number } \\
\text { of tests }\end{array}$} & \multicolumn{2}{|c|}{ Number of positive trends } & \multicolumn{2}{|c|}{ Number of negative trends } \\
\hline & & $p$-value $<5 \%$ & Total & $p$-value $<5 \%$ & Total \\
\hline $\begin{array}{l}\text { Pre-emergence } \\
\text { herbicide (corn) }\end{array}$ & 230 & $\begin{array}{c}19 \\
(8.3 \%) \\
\end{array}$ & $\begin{array}{c}148 \\
(64.3 \%) \\
\end{array}$ & $\begin{array}{c}0 \\
(0 \%) \\
\end{array}$ & $\begin{array}{c}82 \\
(35.7 \%) \\
\end{array}$ \\
\hline $\begin{array}{l}\text { Post-emergence } \\
\text { herbicide (corn) }\end{array}$ & 230 & $\begin{array}{c}5 \\
(2.2 \%) \\
\end{array}$ & $\begin{array}{c}136 \\
(59.1 \%) \\
\end{array}$ & $\begin{array}{c}4 \\
(1.7 \%) \\
\end{array}$ & $\begin{array}{c}93 \\
(40.4 \%) \\
\end{array}$ \\
\hline $\begin{array}{c}1^{\text {st }} \text { insecticide } \\
\text { treatment (apple) }\end{array}$ & 207 & $\begin{array}{c}4 \\
(1.9 \%) \\
\end{array}$ & $\begin{array}{c}109 \\
(52.7 \%) \\
\end{array}$ & $\begin{array}{c}4 \\
(1.9 \%) \\
\end{array}$ & $\begin{array}{c}94 \\
(45.4 \%) \\
\end{array}$ \\
\hline $\begin{array}{c}2^{\text {nd }} \text { insecticide } \\
\text { treatment (apple) }\end{array}$ & 207 & $\begin{array}{c}3 \\
(1.5 \%) \\
\end{array}$ & $\begin{array}{c}89 \\
(43.0 \%) \\
\end{array}$ & $\begin{array}{c}12 \\
(5.8 \%) \\
\end{array}$ & $\begin{array}{c}118 \\
(57.0 \%) \\
\end{array}$ \\
\hline $\begin{array}{c}3^{\text {rd }} \text { insecticide } \\
\text { treatment (apple) }\end{array}$ & 207 & $\begin{array}{c}10 \\
(4.8 \%)\end{array}$ & $\begin{array}{c}106 \\
(51.2 \%)\end{array}$ & $\begin{array}{c}6 \\
(2.9 \%)\end{array}$ & $\begin{array}{c}101 \\
(48.8 \%)\end{array}$ \\
\hline
\end{tabular}


Table 3. Mood test results for the maximum daily rainfall (1981-2040) during the moving interval of 31-day (herbicide) or 11-day (insecticide) centered on the median application day at each year for each site-climate-simulation combination.

\begin{tabular}{|c|c|c|c|c|c|}
\hline \multirow{2}{*}{$\begin{array}{l}\text { Treatment } \\
\text { (crop) }\end{array}$} & \multirow{2}{*}{$\begin{array}{l}\text { Number } \\
\text { of tests }\end{array}$} & \multicolumn{2}{|c|}{ Number of positive trends } & \multicolumn{2}{|c|}{ Number of negative trends } \\
\hline & & $p$-value $<5 \%$ & Total & $p$-value $<5 \%$ & Total \\
\hline $\begin{array}{l}\text { Pre-emergence } \\
\text { herbicide (corn) }\end{array}$ & 230 & $\begin{array}{c}6 \\
(2.6 \%)\end{array}$ & $\begin{array}{c}98 \\
(42.6 \%)\end{array}$ & $\begin{array}{c}19 \\
(8.3 \%)\end{array}$ & $\begin{array}{c}132 \\
(57.4 \%)\end{array}$ \\
\hline $\begin{array}{l}\text { Post-emergence } \\
\text { herbicide (corn) }\end{array}$ & 230 & $\begin{array}{c}12 \\
(5.2 \%)\end{array}$ & $\begin{array}{c}132 \\
(57.4 \%)\end{array}$ & $\begin{array}{c}8 \\
(3.5 \%)\end{array}$ & $\begin{array}{c}98 \\
(42.6 \%)\end{array}$ \\
\hline $\begin{array}{c}1^{\text {st }} \text { insecticide } \\
\text { treatment (apple) }\end{array}$ & 207 & $\begin{array}{c}10 \\
(4.8 \%)\end{array}$ & $\begin{array}{c}107 \\
(51.7 \%)\end{array}$ & $\begin{array}{c}11 \\
(5.3 \%)\end{array}$ & $\begin{array}{c}100 \\
(48.3 \%)\end{array}$ \\
\hline $\begin{array}{l}2^{\text {nd }} \text { insecticide } \\
\text { treatment (apple) }\end{array}$ & 207 & $\begin{array}{c}33 \\
(15.9 \%)\end{array}$ & $\begin{array}{c}103 \\
(49.8 \%)\end{array}$ & $\begin{array}{c}7 \\
(3.4 \%)\end{array}$ & $\begin{array}{c}104 \\
(50.2 \%)\end{array}$ \\
\hline $\begin{array}{l}3^{\text {rd }} \text { insecticide } \\
\text { treatment (apple) }\end{array}$ & 207 & $\begin{array}{c}12 \\
(5.8 \%)\end{array}$ & $\begin{array}{c}108 \\
(52.2 \%)\end{array}$ & $\begin{array}{c}17 \\
(8.2 \%)\end{array}$ & $\begin{array}{c}99 \\
(47.8 \%)\end{array}$ \\
\hline
\end{tabular}


Table 4. Mood test results for the maximum daily rainfall (1981-2040) during the fixed interval of 31day (herbicide) or 11-day (insecticide) centered on the interannual median application day for each siteclimate-simulation combination.

\begin{tabular}{|c|c|c|c|c|c|}
\hline \multirow{2}{*}{$\begin{array}{l}\text { Treatment } \\
\text { (crop) }\end{array}$} & \multirow{2}{*}{$\begin{array}{l}\text { Number } \\
\text { of tests }\end{array}$} & \multicolumn{2}{|c|}{ Number of positive trends } & \multicolumn{2}{|c|}{ Number of negative trends } \\
\hline & & $p$-value $<5 \%$ & Total & $p$-value $<5 \%$ & Total \\
\hline $\begin{array}{l}\text { Pre-emergence } \\
\text { herbicide (corn) }\end{array}$ & 230 & $\begin{array}{c}13 \\
(5.7 \%) \\
\end{array}$ & $\begin{array}{c}110 \\
(47.8 \%) \\
\end{array}$ & $\begin{array}{c}13 \\
(5.7 \%) \\
\end{array}$ & $\begin{array}{c}120 \\
(52.2 \%) \\
\end{array}$ \\
\hline $\begin{array}{l}\text { Post-emergence } \\
\text { herbicide (corn) }\end{array}$ & 230 & $\begin{array}{c}22 \\
(9.6 \%)\end{array}$ & $\begin{array}{c}119 \\
(51.7 \%)\end{array}$ & $\begin{array}{c}7 \\
(3.0 \%)\end{array}$ & $\begin{array}{c}111 \\
(48.3 \%)\end{array}$ \\
\hline $\begin{array}{c}1^{\text {st }} \text { insecticide } \\
\text { treatment (apple) }\end{array}$ & 207 & $\begin{array}{c}9 \\
(4.3 \%) \\
\end{array}$ & $\begin{array}{c}103 \\
(49.8 \%) \\
\end{array}$ & $\begin{array}{c}8 \\
(3.9 \%) \\
\end{array}$ & $\begin{array}{c}104 \\
(50.2 \%) \\
\end{array}$ \\
\hline $\begin{array}{c}2^{\text {nd }} \text { insecticide } \\
\text { treatment (apple) }\end{array}$ & 207 & $\begin{array}{c}34 \\
(16.4 \%) \\
\end{array}$ & $\begin{array}{c}138 \\
(66.7 \%) \\
\end{array}$ & $\begin{array}{c}7 \\
(3.4 \%) \\
\end{array}$ & $\begin{array}{c}69 \\
(33.3 \%) \\
\end{array}$ \\
\hline $\begin{array}{l}3^{\text {rd }} \text { insecticide } \\
\text { treatment (apple) }\end{array}$ & 207 & $\begin{array}{c}16 \\
(7.7 \%) \\
\end{array}$ & $\begin{array}{c}123 \\
(59.4 \%) \\
\end{array}$ & $\begin{array}{c}13 \\
(6.3 \%) \\
\end{array}$ & $\begin{array}{c}84 \\
(40.6 \%) \\
\end{array}$ \\
\hline
\end{tabular}


Table 5. Pesticide transported by surface runoff for each enemy: 60-year mean, difference between past (1981-2010) and future (2011-2040), and standard deviation from three sources of uncertainty. Percent values in parentheses are the mean change relative to the mean pesticide loss. Chemical properties and application rates (Table S3), as well as IUPAC name (Table S4) of each active ingredient are given in supplemental data.

\begin{tabular}{|c|c|c|c|c|c|c|}
\hline \multirow[b]{2}{*}{ Variable } & \multirow[b]{2}{*}{$\begin{array}{l}\text { Enemy } \\
\text { (crop) }\end{array}$} & \multirow[b]{2}{*}{ AI } & \multirow[b]{2}{*}{$\begin{array}{l}\text { Mean value } \\
\text { (g/ha-year) }\end{array}$} & \multicolumn{3}{|c|}{ Standard deviation (g/ha-year) } \\
\hline & & & & Inter-site & $\begin{array}{l}\text { Inter- } \\
\text { realization }\end{array}$ & $\begin{array}{c}\text { Inter- } \\
\text { climate- } \\
\text { simulation }\end{array}$ \\
\hline \multirow[t]{4}{*}{+2} & \multirow{3}{*}{$\begin{array}{l}\text { Weeds } \\
\text { (corn) }\end{array}$} & Atrazine & 1.35 & 1.19 & 1.17 & 0.14 \\
\hline & & Mesotrione & 0.16 & 0.14 & 0.13 & 0.02 \\
\hline & & Glyphosate & 1.26 & 1.84 & 1.22 & 0.16 \\
\hline & \multirow{4}{*}{$\begin{array}{l}\text { Insects } \\
\text { (apple) }\end{array}$} & Phosmet & 0.53 & 0.71 & 0.49 & 0.09 \\
\hline \multirow{7}{*}{$\begin{array}{c}\text { Load } \\
\text { from } \\
1981 \text { to } \\
2040\end{array}$} & & Thiacloprid & 0.27 & 0.31 & 0.17 & 0.04 \\
\hline & & Spinetoram & 0.07 & 0.13 & 0.05 & 0.01 \\
\hline & & Acetamiprid & 0.05 & 0.07 & 0.04 & 0.01 \\
\hline & \multirow{3}{*}{$\begin{array}{c}\text { Apple } \\
\text { scab } \\
\text { (apple) }\end{array}$} & Mancozeb & 0.004 & 0.01 & 0.01 & 0.001 \\
\hline & & Metiram & 0.20 & 0.50 & 0.23 & 0.04 \\
\hline & & Captan & 1.44 & 2.17 & 1.66 & 0.22 \\
\hline & $\begin{array}{l}\text { Fire blight } \\
\text { (apple) }\end{array}$ & $\begin{array}{l}\text { Streptomycin } \\
\text { sulfate }\end{array}$ & 1.03 & 1.47 & 0.82 & 0.20 \\
\hline \multirow{7}{*}{$\begin{array}{c}\text { Load } \\
\text { change } \\
\text { between } \\
1981- \\
2010\end{array}$} & \multirow{3}{*}{$\begin{array}{l}\text { Weeds } \\
\text { (corn) }\end{array}$} & Atrazine & $-0.001(-0.1 \%)$ & 0.05 & 0.03 & 0.28 \\
\hline & & Mesotrione & $-0.0001(-0.1 \%)$ & 0.01 & 0.004 & 0.04 \\
\hline & & Glyphosate & $0.01(+0.5 \%)$ & 0.05 & 0.06 & 0.34 \\
\hline & \multirow{4}{*}{$\begin{array}{l}\text { Insects } \\
\text { (apple) }\end{array}$} & Phosmet & $0.01(+1.0 \%)$ & 0.09 & 0.03 & 0.15 \\
\hline & & Thiacloprid & $0.02(+5.5 \%)$ & 0.03 & 0.01 & 0.06 \\
\hline & & Spinetoram & $0.001(+1.7 \%)$ & 0.004 & 0.002 & 0.02 \\
\hline & & Acetamiprid & $-0.0001(-0.2 \%)$ & 0.01 & 0.003 & 0.02 \\
\hline \multirow{4}{*}{$\begin{array}{c}\text { and } \\
2011- \\
2040\end{array}$} & Apple & Mancozeb & $0.0004(+8.2 \%)$ & 0.001 & 0.0004 & 0.002 \\
\hline & scab & Metiram & $0.02(+11.5 \%)$ & 0.05 & 0.02 & 0.07 \\
\hline & (apple) & Captan & $0.13(+9.2 \%)$ & 0.18 & 0.12 & 0.45 \\
\hline & $\begin{array}{l}\text { Fire blight } \\
\text { (apple) }\end{array}$ & $\begin{array}{l}\text { Streptomycin } \\
\text { sulfate }\end{array}$ & $0.01(+1.1 \%)$ & 0.15 & 0.02 & 0.37 \\
\hline
\end{tabular}


Figure 1

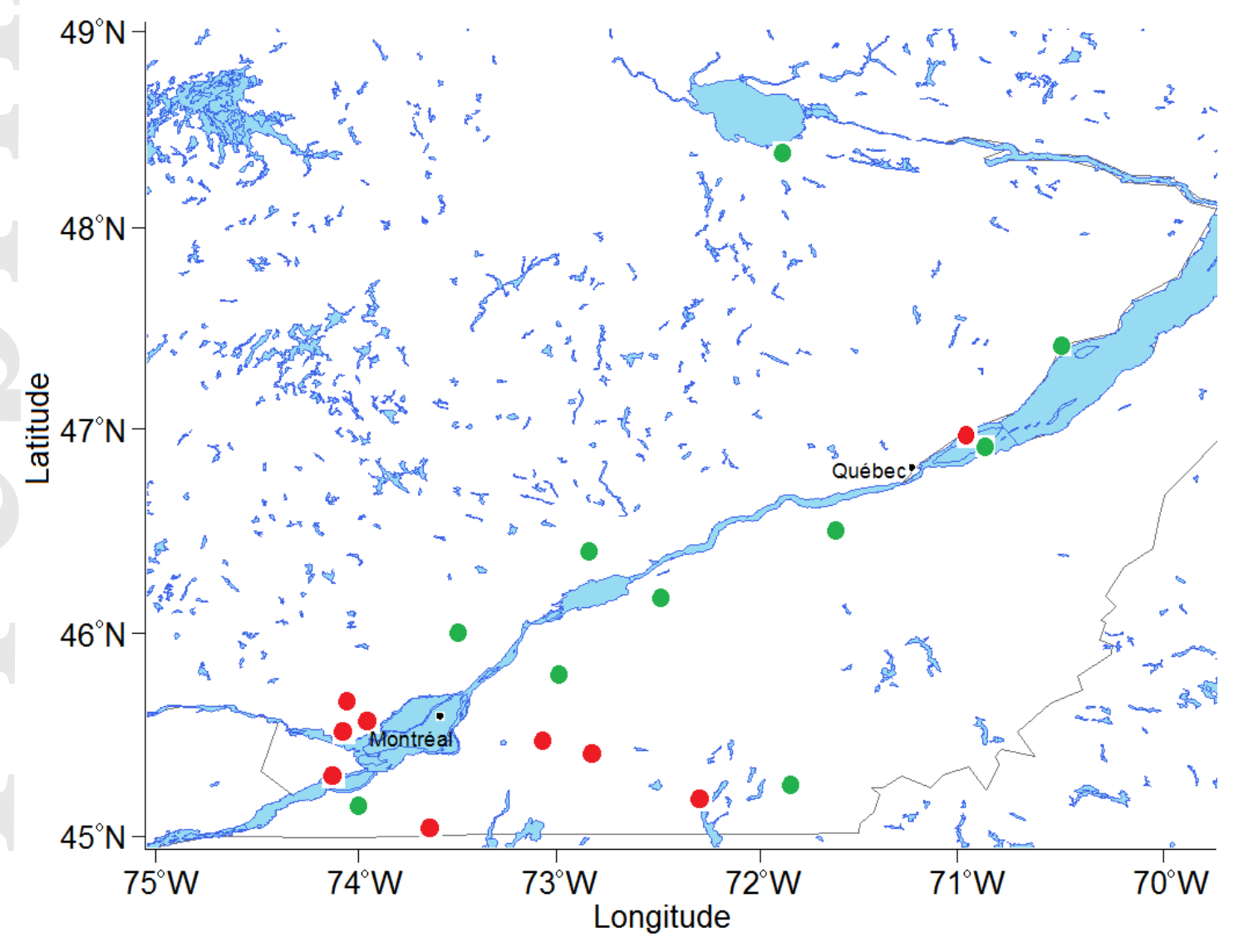

This article is protected by copyright. All rights reserved 
Figure 2

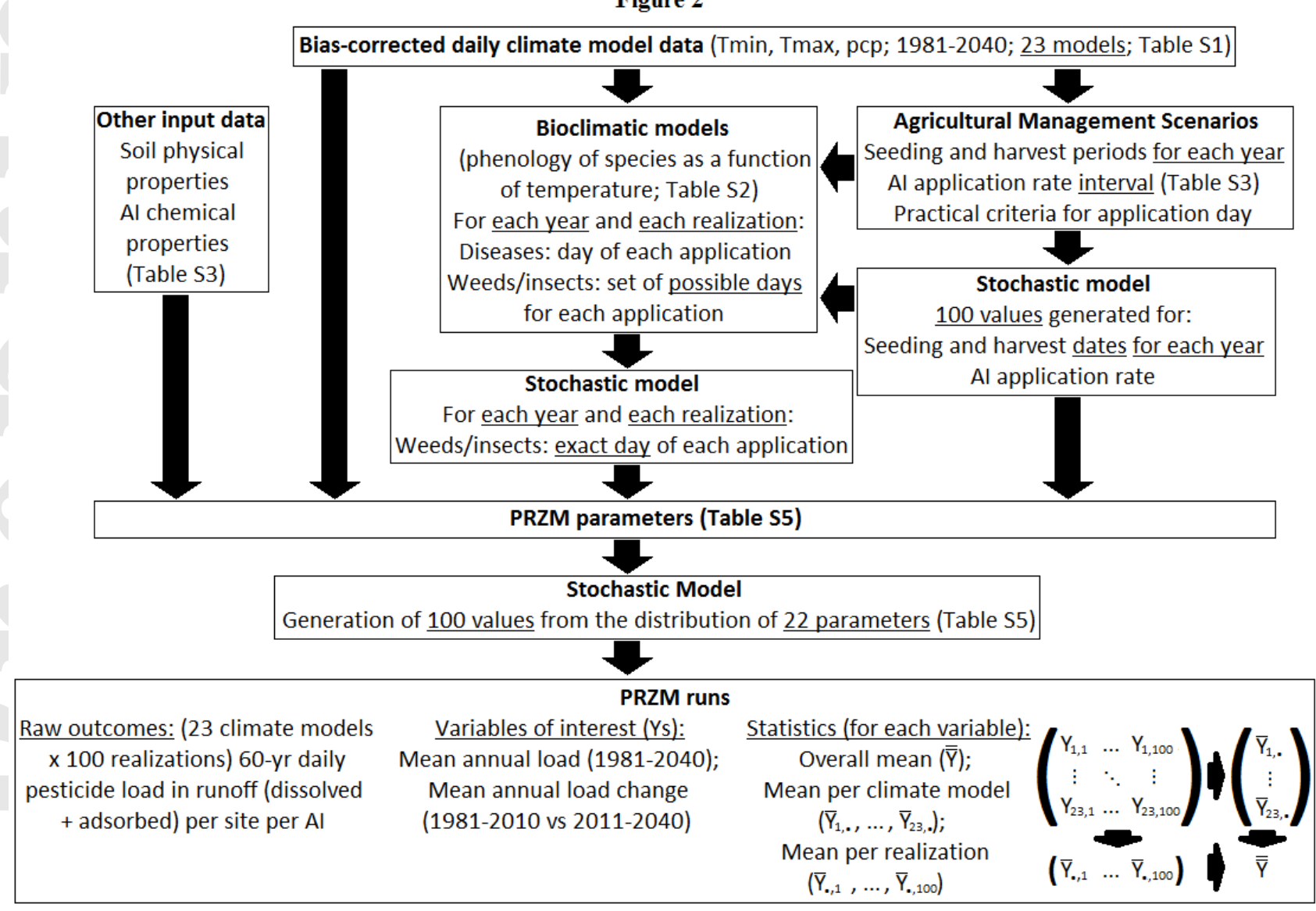

This article is protected by copyright. All rights reserved 
Figure 3

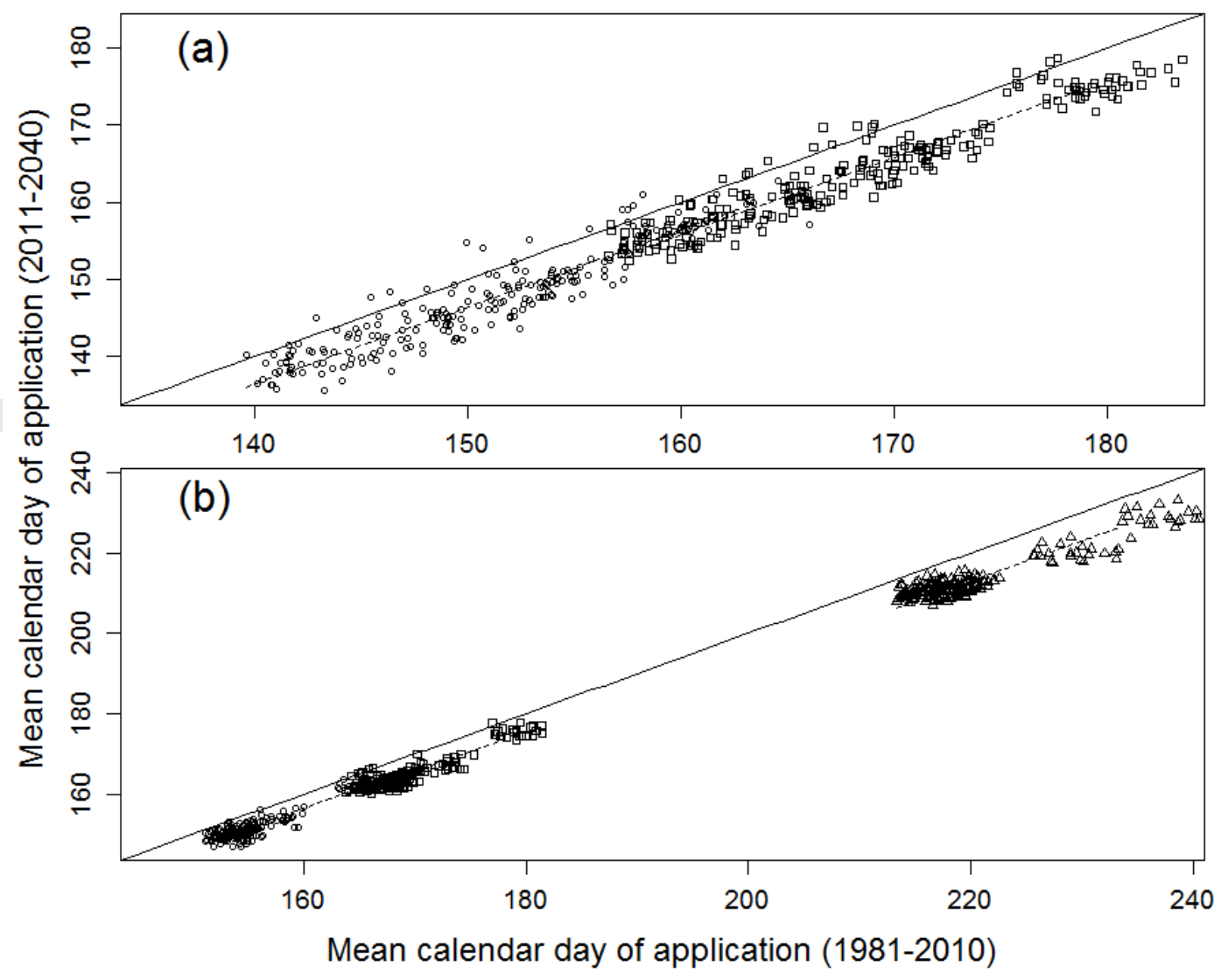

This article is protected by copyright. All rights reserved 
Figure 4
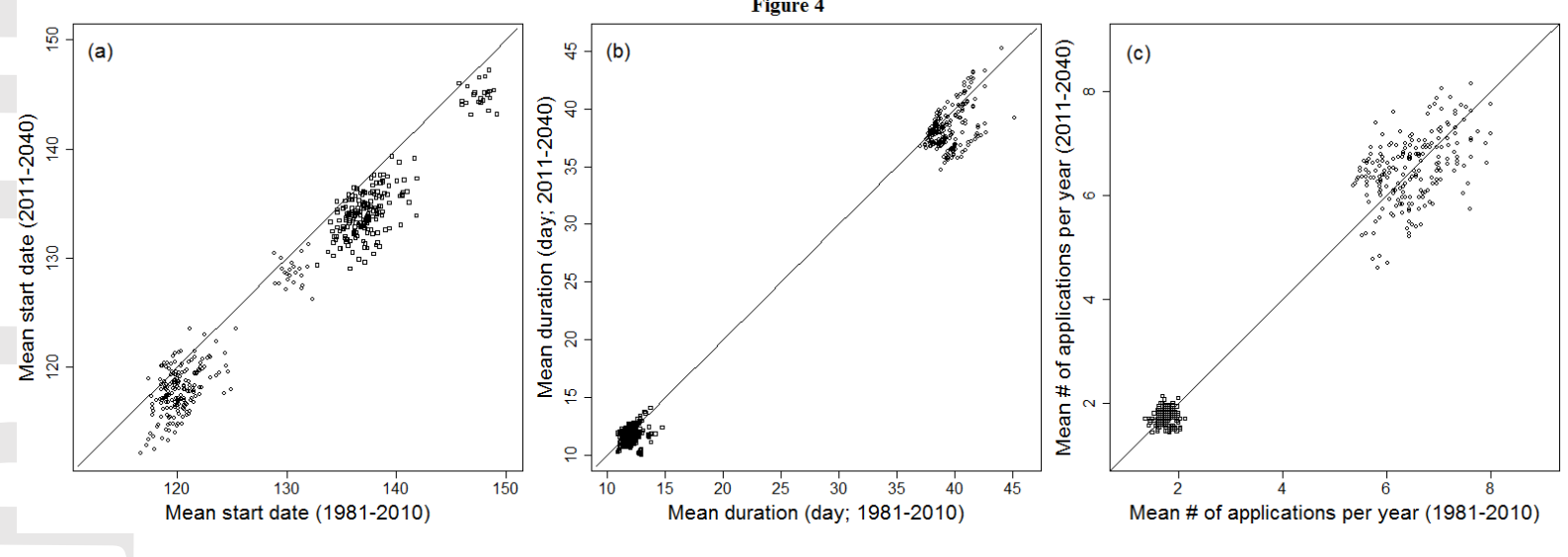

This article is protected by copyright. All rights reserved 
Figure 5

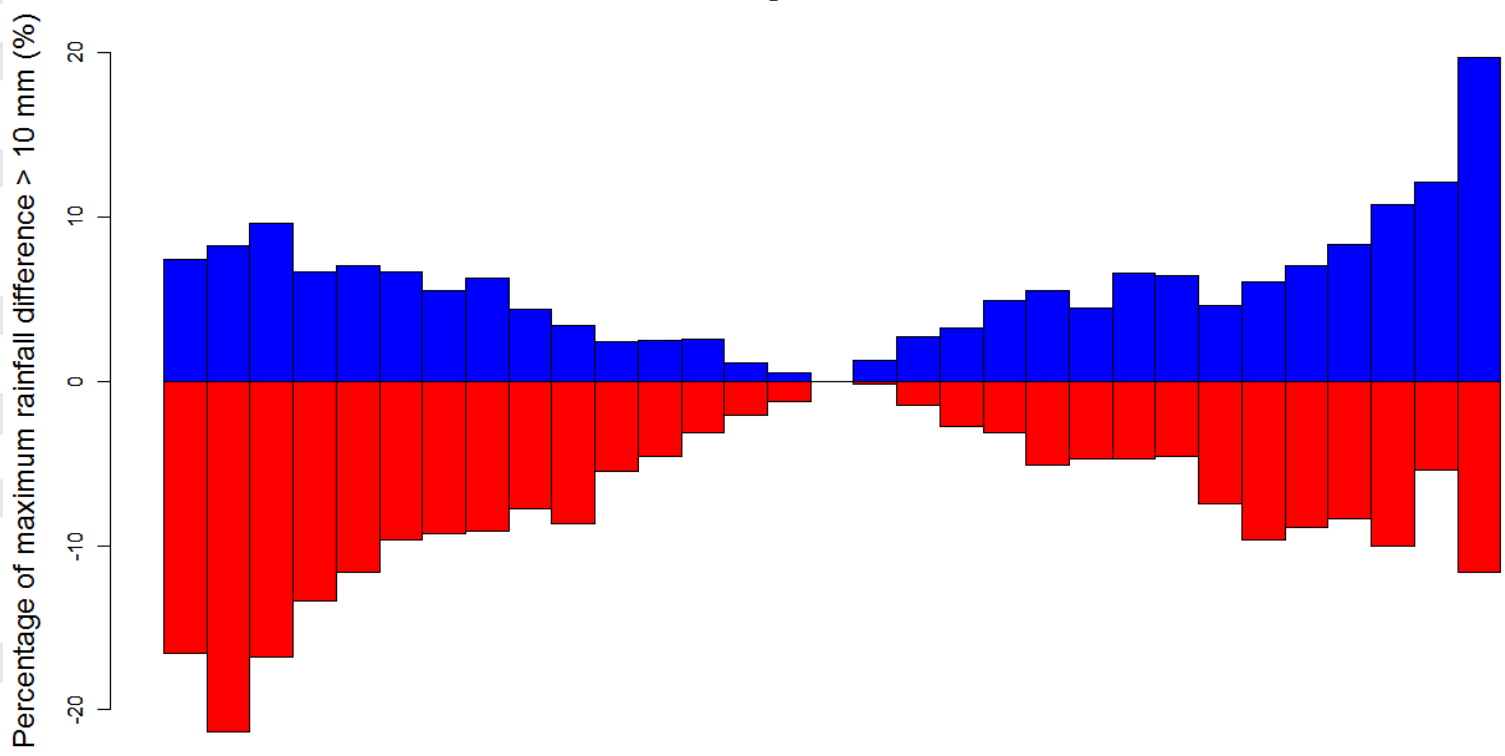

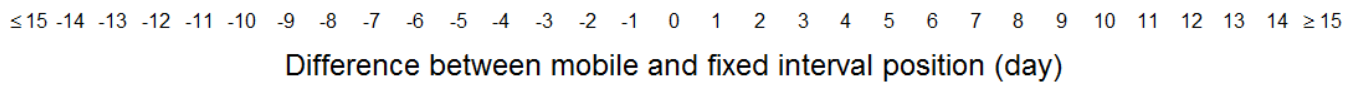

This article is protected by copyright. All rights reserved 

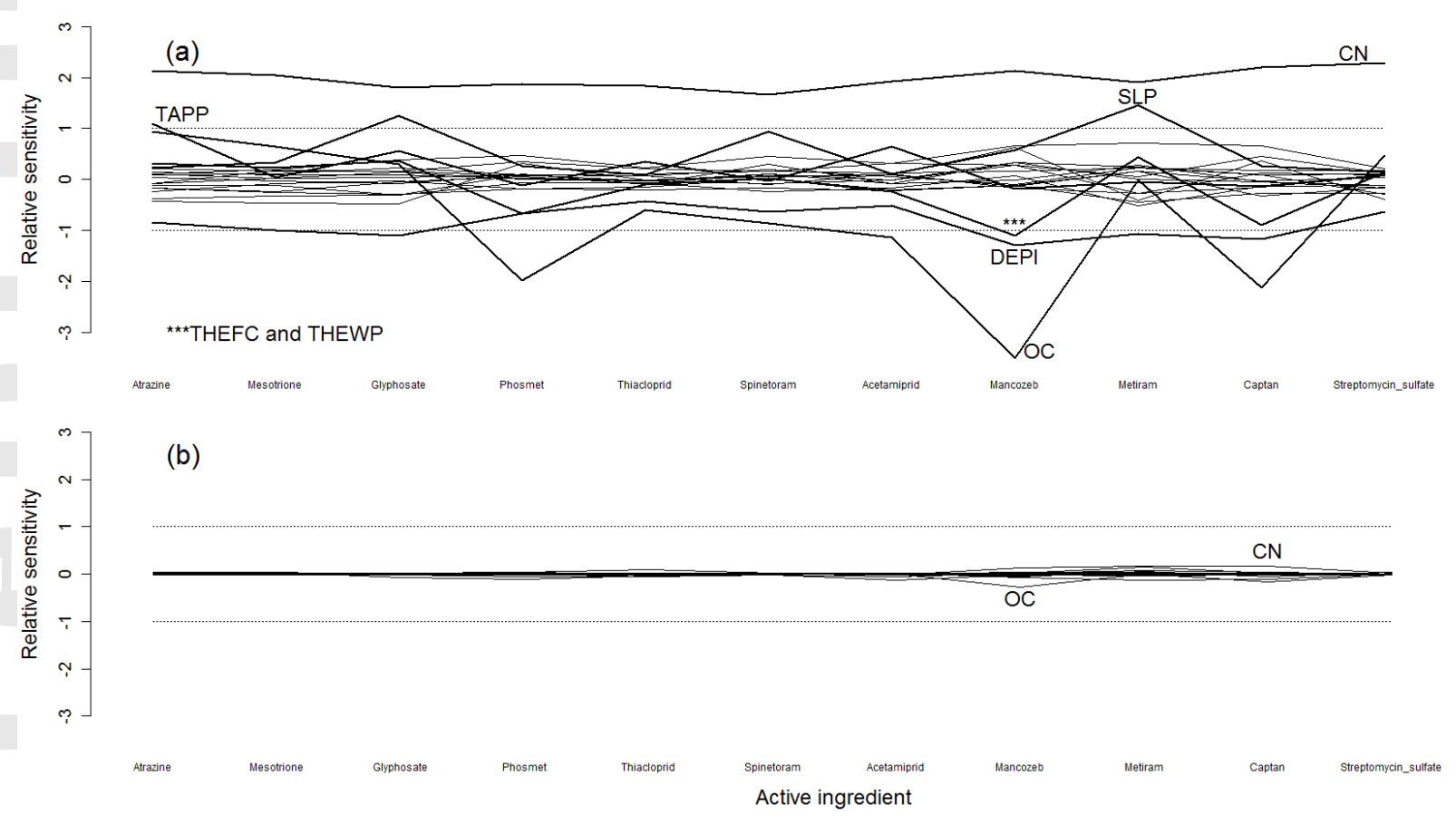

This article is protected by copyright. All rights reserved 